zoological specimens which have lasted to our day. With the exception of a white giraffe which has been lent by Rowland Ward, Ltd., all the specimens are drawn from the Museum collections. They show to much greater advantage in their present setting than crowded together in glazed cases in the Mammal Galleries. The exhibit, which has been arranged by Capt. J. G. Dollman, was opened to the public on May 31.

\section{New Botanical Collections}

THE Department of Botany, British Museum (Natural History), has received some noteworthy additions during the last two months. His Majesty the King has placed on permanent loan a further collection of Nepal plants presented to him by His Highness the Maharaja of Nepal. The present consignment numbers 253 specimens, which were collected by Prof. K. Sharma; Major L. Dhwoj, who was responsible for the previous collections, died during the expedition. The value of the collection is that it is from previously unexplored mountains. Another collection which will add to our knowledge of the floristics of the Himalayan region has been presented by Capt. F. Kingdon-Ward. It consists of 1233 specimens, and is from the Upper Irrawaddy and the Burma-Tibet frontier. A valuable addition is the gift of the Boswell-Syme British Herbarium by Mr. Frederick J. Hanbury. This contains about 20,000 sheets, in fourteen mahogany cabinets, and will be kept as a separate collection. Boswell-Syme (18221888) was the editor of the third edition of "English Botany ", and the specimens on which his remarkably accurate descriptions were based are in the collection. The herbarium was purchased by Mr. Hanbury on Boswell-Syme's death, and is in excellent condition. British botanists will now be free to consult the remarkably long series of species which are rarely well represented in modern herbaria. Mr. A. Vernay has presented a set of plants obtained on the Vernay-Lang expedition to the Kalahari desert. This area is very poor floristically, and the 264 species, including twenty type gatherings, are consequently of value in extending our knowledge of distribution.

\section{Acquisitions at the Natural History Museum}

Among the chief recent acquisitions in the Zoological Department of the British Museum (Natural History) are 60 mammals and 590 birds obtained by the Vernay-Lang Expedition to the Kalahari Desert, presented by Mr. A. S. Vernay; the mammals include specimens of 11 forms recently described as being new to science by Mr. Austin Roberts of the Transvaal Museum. Another important gift received from Mr. Vernay is a collection of 184 mammals, 29 reptiles, 34 fishes, and 500 butterflies obtained by Capt. Beresford Holloway, who accompanied Mr. Vernay on his recent expedition to the Malay Peninsula. This collection comprises many rare species, including a specimen of the rare Rhinoceros sondaicus, which is now being mounted, at the expense of the donor, for exhibition in the Museum. Purchases for the Department of Geology include a specimen of the teeth of an extinct shark, Edestus, from Devonian rocks of Rhenish Prussia. The median teeth of Edestus, instead of falling away after use as in all other sharks, remained attached to their successors, forming in the course of time an external dental spiral which must have hung over the point of the jaws and sometimes contained no less than 150 teeth. Prof. G. Vibert Douglas has collected and presented to the Department of Minerals a large series of rocks illustrating the geology and mineralisation of several mines in the 'copper belt' of Northern Rhodesia and Katanga. Samples of volcanic dust which fell after the recent eruptions (April 11-12) in the Andes have been presented by the Times Publishing Co. and by Messrs. H. W. Nelson, Ltd.

\section{British Science Guild}

AT the annual meeting of the British Science Guild held on May 25, Sir Samuel Hoare was re-elected president for the ensuing year, and affirmed his faith in the aims of the Guild. The annual report shows a year of useful work. Perhaps its most interesting feature is the attempt which the Guild is making, in conjunction with the Association of Scientific Workers, to provide an adequate channel for bringing before Parliament the views of scientific men. A Science Advisory Council is being set up, and it is intended that this Council shall be in some sense comparable with the Federation of British Industries, in the sense that it shall be the liaison body for providing contact with Parliament in connexion with scientific and technical matters coming before the House. The success of the projected Council will, of course, depend on the degree in which it enjoys the co-operation of scientific and technical societies, a number of which have already agreed to participate. The extent of its activities, however, will be mainly determined by that of the funds placed at its disposal, and in this aspect the matter has yet to be put on a satisfactory basis.

\section{Research and Industry}

IN a recent article in the Journal of the Textile Institute, on "Cotton Research and Academic Physies", Dr. F. T. Peirce points out that the tendency of men of science to get into ruts of thought is partly responsible for the tardiness of the academic mind to appreciate and interpret the problems of technology in a way that is essential for the interpenetration of science and industry. On the other hand, while as one consequence of specialisation every research worker is accustomed in his reading to slur over matter which he cannot or need not understand, the industrialist is apt to be offended if he encounters matter which is incomprehensible to him even though the practical conclusions are clear. Without claiming that scientific research is a complete cure for all the troubles of industry, Dr. Peirce urges that it is a method of securing the most effective use of available resources, and shows how, within the experience of the cotton industry, impersonal scientific methods have succeeded in saving efforts and resolving difficulties in the relations of firms or branches of the industry with

No. 3266, VoL. 129] 
employees and between service departments. Cooperation may ultimately lead the ideal of team work to merge in that of ' group work', groups having only their own ignorance or inefficiency as enemy, and in organisation by technical processes rather than by sciences.

THE matter of publication is not without concern to the relations of science and industry, as pointed out by Dr. Peirce, and a generous policy of publication for lines of pure scientific interest has a stimulating effect on the research staff from which the industry itself is the first to benefit. Publication assists in securing the recognition and interest from the universities, which are essential for open discussion, for combating the natural secretiveness of industry, and for creating a technical literature in which systematic cross reference becomes possible. These and other problems relating to the scientific reputation of the individual, the place of individual initiative and originality in co-operative research, are aspects of the relations between science and industry which are a modern phase of the conflict between authority and liberty. Much also remains to be done in redressing the present neglect of the borderland sciences, and cotton itself is of special interest in the borderland of physics. Finally, Dr. Peirce suggests that by overcoming the technical difficulties of industry the scientific worker may remove obstacles to the development of beauty, and thus contribute to the artistic as well as to the humane aspect of industry.

\section{Social Discontent and its Remedy}

IT is not altogether a new explanation of the social ills of the day to find a psychological rather than an economic explanation, but the theme is one that may well be stressed, and is ably expounded by Mr. H. A. Bruce in a paper on "The Sources of American Discontent" (Proc. Amer. Acad. Arts and Sci., vol. 67, No. 3, Feb. 1932). The social evils and discontent which $\mathrm{Mr}$. Bruce cites as being prevalent in America to-day are no less evident in many parts of Europe, and he finds the chief cause to lie in modern industrialisation, which not only narrows and starves the needs of the individual life, but also results in that crowding which leads to crowd mentality and all its drawbacks. The present state of affairs leads to discontent, adds to the prison population, the numbers of mental and nervous wrecks, and takes a mounting toll of suicides and lives shortened by bodily diseases promoted by mental stress. Mr. Bruce admits the seriousness of the problem and the difficulties of solution when national policies are determined by majorities infused with the crowd spirit and on an arrested level of mental activity, but he makes the suggestion that the crowd spirit may itself be used to contribute to the acceptance of a wiser philosophy of life than is summed up in making money, spending money, and amusing oneself. Intensive education of a far-spreading kind is the agency to apply in changing the outlook of industrialised peoples, and leading them to an appreciation of values other than those which prevail to-day.

No. 3266, VoL. 129]

\section{Hydrogen and its Uses}

Dr. E. F. Armstrong recently delivered a lecture on hydrogen and its uses before the Royal Society of Arts (J. Roy. Soc. Arts, May 6). Two important methods of preparation of hydrogen are from water gas and coke oven gas. The carbon monoxide in water gas is oxidised to carbon dioxide by passing a mixture of the gas and steam over a catalyst containing iron oxide, the hydrogen of the reacting steam being set free. The small residue of carbon monoxide is removed by absorption under 200 atm. pressure. The preparation from coke oven gas depends on purification by washing and fractional cooling, whereby first the methane and then the carbon monoxide is removed. The cost of production by either method under the most favourable conditions is about $1 s$. per thousand cubic feet of hydrogen. The principal uses of hydrogen are for the hydrogenation of fats, in which liquid oils are converted into solid fats by taking up hydrogen in the presence of small quantities of nickel; the hydrogenation of other organic materials, including mineral oil, tar, and coal; and the production of synthetic ammonia. The conversion of coal into oil by treatment with hydrogen under pressure involves the use of an elaborate and costly plant; and so far as the production of petrol is concerned, the cost is put down at $7 d$. $-8 d$. per gallon, as compared with a price of less than $2 d$. per gallon at the oilfield. The prices may alter in future in favour of petrol from coal. If hydrogen is ever required in larger quantities by the oil industry, it could be obtained from the methane of natural gas or refinery waste gas, which readily reacts with steam to form hydrogen and carbon dioxide.

\section{The National Physical Laboratory}

The Report of the National Physical Laboratory for the year 1931 is an illustrated quarto volume of 131 pages (London: H.M. Stationery Office, $15 s$. net). As usual, it gives a readable and interesting account of the progress of the work of each department without introducing technical details, and equally as usual, that progress must be gratifying to the Board and to the staff. The new physics building is now in use and the old quarters of physics are occupied by electrical standards. The compressed air tunnel building is completed, the new tank will be completed this year, and the new acoustics building has been commenced. Dr. W. Rosenhain has left to take up other work, Prof. C. H. Desch of Sheffield succeeds him, while Dr. W. E. Dye has been lost by death. Ninety-seven official papers by members of the staff have been published during the year in the scientific or technical journals or in the proceedings of societies. We note the determination of the yard and metre in terms of the wave-length of the red cadmium line, the accurate measurement of time for radio frequencies, and an international agreement as to colour standardisation. Routine tests of almost all types have with few exceptions, decreased. In the watch tests, the success of one Swiss firm is very remarkable. 